\title{
Non-pharmacological therapies for the treatment of post-traumatic stress disorder among emergency responders: a scoping review
}

\author{
Terapias não farmacológicas no tratamento de transtorno do estresse \\ pós-traumático em emergencistas: revisão de escopo \\ Terapias no farmacológicas de tratamiento del trastorno de estrés \\ postraumático en emergencistas: revisión de alcance
}

How to cite this article:

Nascimento JCP, Santos KVG, Dantas JKS, Dantas DV, Dantas RAN. Non-pharmacological therapies for the treatment of post-traumatic stress disorder among emergency responders: a scoping review. Rev Esc Enferm USP. 2021;55:e03724. doi: https://doi.org/10.1590/S1980-220X2020011603724

Jessica Cristhyane Peixoto Nascimento $^{1}$

(D) Kauanny Vitoria Gurgel dos Santos ${ }^{1}$

(iD) Joyce Karolayne dos Santos Dantas $^{1}$

\section{Daniele Vieira Dantas ${ }^{1}$ \\ Rodrigo Assis Neves Dantas ${ }^{1}$}

${ }^{1}$ Universidade Federal do Rio

Grande do Norte, Departamento de

Enfermagem, Natal, RN, Brazil.
Corresponding author:

Jessica Cristhyane Peixoto Nascimento BR 101, s/n - Lagoa Nova CEP 59070-405 - Natal, RN, Brazil jessicacristhy@gmail.com

\begin{abstract}
Objective: Identify non-pharmacological therapies for the treatment of post-traumatic stress disorder in emergency responders. Method: Scope review according to the guidelines of the Joanna Briggs Institute and the PRISMA-ScR protocol. A search was conducted in nine databases, portals of theses and dissertations, and using an electronic search engine. Results: In total, 23 studies were selected and analyzed, and then categorized into six thematic fields - therapy with omega 3 food supplement, art therapy, physical exercise therapy, mindfulness-based therapy, therapy with elements of nature, and psychotherapy - which were considered non-pharmacological treatments for this psychopathology among emergency responders, as well as the use of psychotherapy via telehealth as an option for treatment. Conclusion: More evidence supporting diet therapy is required, while the other therapeutic options presented positive results, finding support in national and international recommendations of treatment and clinical practice.
\end{abstract}

\section{DESCRIPTORS}

Stress Disorders, Post-Traumatic; Emergency Responders; Complementary Therapies; Emergency Nursing; Review. 


\section{INTRODUCTION}

Post-traumatic stress disorder (PTSD) is a mental disorder resulting from single or continuous exposure to one or more traumatic events - either experiencing or witnessing them, putting one's own life or someone else's life at risk, or posing threats to an individual's physical, mental or moral integrity ${ }^{(1)}$.

It is a diagnosis contained in the Diagnostic and Statistical Manual of Mental Disorders, 5th Edition (DSM5), based on three symptomatic aspects: reliving of the trauma - presenting symptoms such as intense fear, helplessness, recurring thoughts and dreams referring to the event; hyperexcitability - tachycardia, sleep disorders, hypervigilance, mood swings; and avoidance - attitudes of social withdrawal and social isolation ${ }^{(2)}$.

Emergency responders are often in rescue or first aid situations, constantly exposed to potentially traumatic events in their work routines. In this sense, studies report a higher incidence of PTSD in this population when compared to usual citizens, making this disorder a subject of utmost investigation for these professionals ${ }^{(3)}$.

Post-traumatic stress disorder is identified according to the criteria defined in the DSM-5: presence of a traumatic event, at least one symptom related to reliving of the trauma, at least one symptom associated with avoidance, two or more symptoms linked with negative mood swings, two or more symptoms linked with hyperexcitability, persistence of symptoms for more than one month, and difficulties in daily life due to the onset of symptoms ${ }^{(1)}$.

Post-traumatic stress disorder is diagnosed through the report of patients who seek a health service or are referred to the health service by family, friends or coworkers; and through screening of signs and symptoms conducted by health professionals from primary care networks and hospitals, and occupational nurses and physicians, or specialized services when they report the symptoms contained in the DSM-5 $5^{(4-9)}$

Studies, manuals and national and international guidelines show there are two types of PTSD treatment: pharmacotherapy or psychotherapy; the latter being the most recommended because, in the long run, it has benefits with fewer adverse effects. However, even with the recommendation of non-pharmacological therapies for PTSD treatment, since it is an anxiety disorder recently included in the DSM, there are still few studies addressing PTSD among emergency responders, and most of these studies are about prevention strategies and initial treatment before the three-month period for disease chronification $^{(10-11)}$.

The manual of the American Psychological Association, the Australian PTSD Guideline, the guideline from the United States Department of Veterans Affairs, the Canadian guideline for clinical practice in the management of PTSD, and the clinical protocol for PTSD from Santa Catarina offer recommendations for psychotherapies as the best choice for the treatment of PTSD, and the technical guide for PTSD treatment issued by the Ministry of Justice and Public Security of Brazil provides therapeutic alternatives that include psychotherapy, pharmacological therapies, and integrative and complementary therapies for PTSD, without a preferred therapy ${ }^{(5-9,12)}$.

Therefore, in order to provide an overview of the studies that address non-pharmacological therapeutic alternatives for the treatment of PTSD in emergency responders, and sustain the recommendations offered in the manuals, protocols, guidelines, and technical guides for the treatment of PTSD, the following study question was developed: What non-pharmacological therapies are used for the treatment of PTSD among emergency responders?

This study aimed to identify non-pharmacological therapies for the treatment of PTSD in emergency responders described in the literature.

\section{METHOD}

\section{Studi DESIGN}

This is a scoping review to map topics that have not been fully studied or to further study a certain subject. This review was based on the recommendations of the Joanna Briggs Institute ${ }^{(13)}$, using the protocol Preferred Reporting Items for Systematic Reviews and Meta-Analyses Extension for Scoping Reviews (PRISMA-ScR) ${ }^{(14-15)}$, and it was registered in the Open Science Framework platform for scientific papers.

\section{Population}

The study question was developed according to the PCC (Population, Concept and Context) mnemonic strategy, with emergency responders defined as the population, non-pharmacological therapies as the concept, and the use of these therapies in the treatment of PTSD as the context.

\section{Data collection}

Studies about non-pharmacological treatments of PTSD in emergency responders, with a description of the treatment, target audience and outcome, published online in any language, with full text available, and with no time frame, were selected for this literature review. In this study, emergency responders included police officers, firefighters, pre-hospital professionals, rescuers, paramedics, nurses, and emergency physicians. Studies with military personnel and war veterans were also included due to the similarity to public security services and frequent exposures to traumatic events involved in the profession.

Duplicate studies were considered only once. Letters to the editor, studies that prioritized railway workers or retired workers, children and adolescents, civilians in general, and studies with animal models were all excluded, as they did not analyze the target population.

This study was conducted in two stages:

\section{StAge 1: DATABASE SEARCH}

Database search was conducted in July 2020 simultaneously by two people, with access through the academic community of the Journal Portal of the Coordination for the 
Improvement of Higher Education Personnel (Coordenação de Aperfeiçoamento de Pessoal de Nivel Superior-CAPES). The following controlled descriptors from the Medical Subject Headings (MeSH) were selected: Therapy, Therapeutics, Disease Management, Complementary Therapies, Stress Disorders, PostTraumatic, PTSD, Occupational Diseases, Occupational Stress, Emergency Responders, Rescue Workers, and Rescue Work. After initial testing to obtain relevant results following the use of controlled descriptors, the terms were selected and combined as indicated in Chart 1.

Specific databases of studies in the field of psychology (PsycINFO) and focused on PTSD (PTSDpubs) were included in order to ensure studies relevant to the study theme.

Chart 1 - Syntaxes of combined descriptors in the scientific database search.

\begin{tabular}{|c|c|}
\hline Database & Syntax adopted \\
\hline WOS* & $\begin{array}{l}\text { TS }=(\text { Therapy OR Therapeutics OR Disease } \\
\text { Management OR Complementary Therapies) AND } \\
T S=(\text { Stress Disorders, Post-Traumatic OR PTSD) AND } \\
\text { TS }=(\text { Occupational Diseases OR Occupational Stress OR } \\
\text { Emergency Responders OR Rescue Workers OR Rescue } \\
\text { Work) }\end{array}$ \\
\hline Scopust & $\begin{array}{l}\text { (KEY ("Therapy" OR "Therapeutics" OR "Disease } \\
\text { Management" OR "Complementary Therapies") AND } \\
\text { KEY ("Stress Disorders, Post-Traumatic" OR "PTSD") } \\
\text { AND KEY ("Occupational Diseases" OR "Occupational } \\
\text { Stress" OR "Emergency Responders" OR "Rescue } \\
\text { Workers" OR "Rescue Work")) }\end{array}$ \\
\hline CINAHL\# & $\begin{array}{l}\text { (SU (Therapy OR Therapeutics OR Disease } \\
\text { Management OR Complementary Therapies)) AND (SU } \\
\text { (Stress Disorders, Post-Traumatic OR PTSD)) AND (SU } \\
\text { (Occupational Diseases OR Occupational Stress OR } \\
\text { Emergency Responders OR Rescue Workers OR Rescue } \\
\text { Work)) }\end{array}$ \\
\hline PsycINFO§ & $\begin{array}{l}\text { (MeSH: Therapy OR MeSH: Therapeutics OR MeSH: } \\
\text { Disease Management OR MeSH: Complementary } \\
\text { Therapies) AND (MeSH: Stress Disorders, Post- } \\
\text { Traumatic OR MeSH: PTSD) AND (MeSH: } \\
\text { Occupational Diseases OR MeSH: Occupational Stress } \\
\text { OR MeSH: Emergency Responders OR MeSH: Rescue } \\
\text { Workers OR MeSH: Rescue Work) }\end{array}$ \\
\hline MEDLINE\| & $\begin{array}{l}\text { ((((therapeutics[MeSH Terms]) OR (disease } \\
\text { management[MeSH Terms])) OR (complementary } \\
\text { therapies[MeSH Terms])) AND ((post traumatic } \\
\text { stress disorders[MeSH Terms]) OR (PSTD[MeSH } \\
\text { Terms])) AND ((occupational diseases[MeSH Terms]) } \\
\text { OR (occupational stress[MeSH Terms]) OR (rescue } \\
\text { work[MeSH Terms]) OR (emergency responders[MeSH } \\
\text { Terms])))) }\end{array}$ \\
\hline PTSDpubs \| & $\begin{array}{l}\text { ("Therapy" OR "Therapeuthics" OR "Disease } \\
\text { Management"OR "Complementary Therapies") AND } \\
\text { ("Stress Disorders, Post-Traumatic" OR "PTSD") AND } \\
\text { ("Occupational Diseases" OR "Occupational Stress" } \\
\text { OR "Emergency Responders"OR "Rescue Workers" OR } \\
\text { "Rescue Work") }\end{array}$ \\
\hline
\end{tabular}

*Web of Science, $†$ Sciverse Scopus, $\ddagger$ Cumulative Index to Nursing and Allied Health Literature, $\S$ Medical Literature Analysis and Retrieval System Online, ||PTSDpubs Database.
Stage 2: Search in an electronic SeArCh enGine and GREY LITERATURE

The second stage was also conducted in July 2020, after the database search. It was conducted through Google Scholar, with the keywords "Treatment", "PTSD", "First Responders", "Management of PTSD", "Emergency Personnel", "Complementary Therapies" and "Alternative Therapies".

The search was also conducted in the Catalog of Theses \& Dissertations - CAPES, the Brazilian Digital Library of Theses and Dissertations (BDTD), and the Digital Library of Theses and Dissertations of the Universidade de São Paulo using the following keywords in English: post traumatic stress disorder, treatment and alternative treatment; and keywords in Portuguese transtorno de estresse pós-traumático, tratamento, terapias alternativas, and tratamento alternativo.

\section{DATA PROCESSING AND ANALYSIS}

After selecting the studies, they were arranged in a structured form containing information of authors, year and country, intervention and target audience, outcome, study design, level of evidence, and level of recommendation according to the Oxford Centre for Evidence-Based Medicine ${ }^{(16)}$. Then they were categorized according to the type of intervention and explained as treatment mechanisms for post-traumatic stress disorder in emergency responders.

\section{RESULTS}

The initial search in the databases found 399 results. After reading titles and abstracts by the authors independently, 28 studies were selected for full text reading, which allowed the identification of 15 studies that met the inclusion criteria. Disagreements were resolved by consensus among the authors. They tried to contact four authors of the studies, with no response until the date of this submission.

The search in databases of dissertations and theses found 177 studies, 40 of them were selected for abstract reading and three for full text reading, but none of them met the inclusion criteria as they analyzed civilians, children, adolescents, university students, and cancer patients. The search using an electronic search engine found 8 studies that met the inclusion criteria after full text reading - all of them were published in scientific journals.

This review included 23 studies (Figure 1), which addressed diet supplement techniques with omega 3, cognitive behavioral techniques, eye movement desensitization and reprocessing (EMDR), eclectic psychotherapy, interactive psychotherapy, cognitive processing therapy, exposure therapy, animal-assisted therapy, horticultural therapy, yoga practice, mindfulness-based therapy, and physical exercise, as described in Chart 2. 


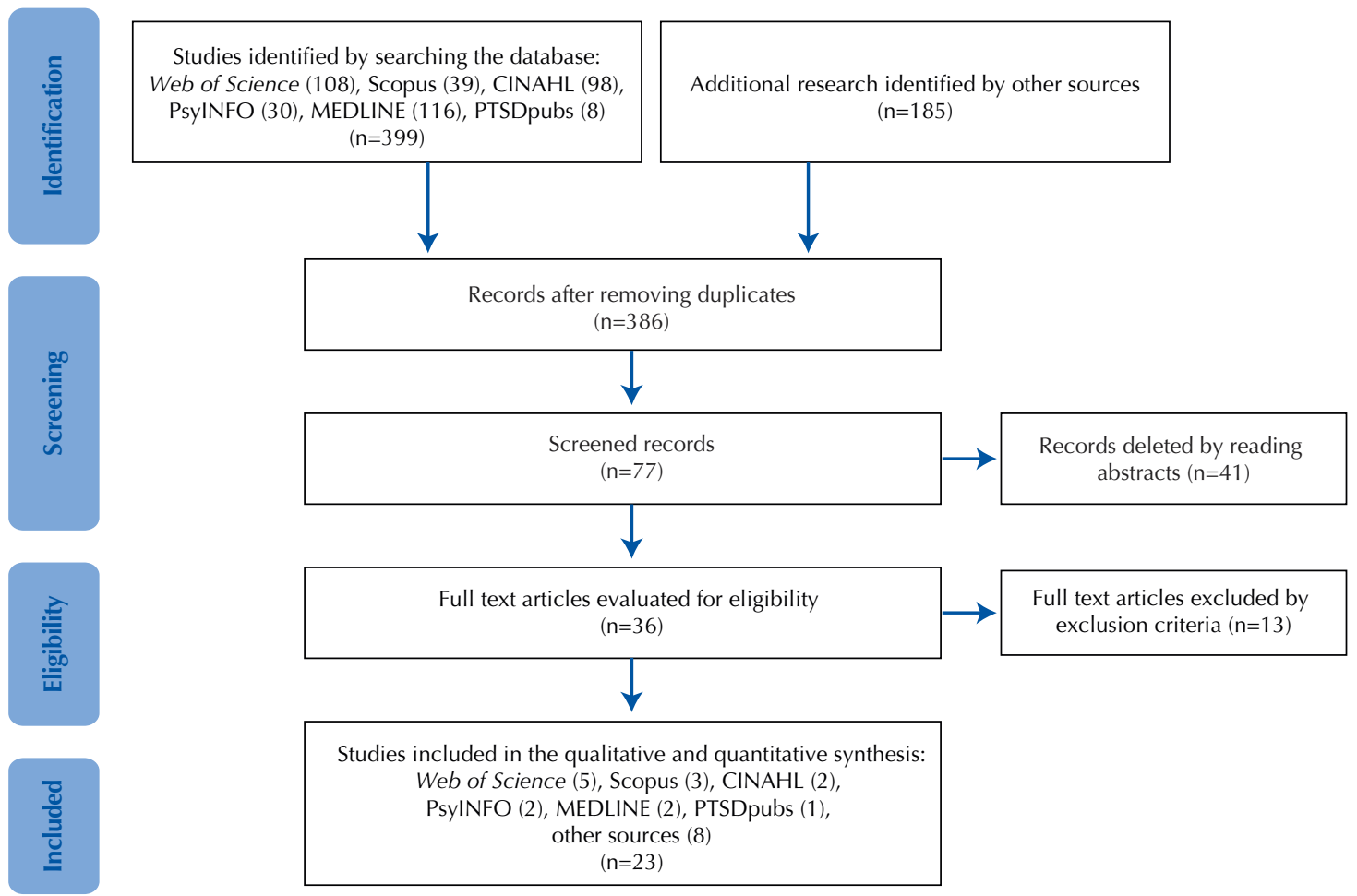

Figure 1 - PRISMA-ScR flowchart.

Of all 23 studies, $82 \%$ ( $n=19)$ were characterized as original studies, using study designs such as randomized controlled or non-controlled trials, cohort studies, case reports, and observation of clinical results; $18 \%(n=4)$ were review studies. Most publications 61\% ( $\mathrm{n}=14)$ were conducted in the United States of America (USA), followed by England $(n=3)$, studies in more than one country $(n=2)$, and Japan, the Netherlands, Australia, and Saudi Arabia $(\mathrm{n}=1)$.

Level of evidence 2 and level of recommendation $B$ were found in $61 \%$ of the studies $(n=14)$. The level of evidence ranged from 1 to 5 , in which the lower the number, the higher the level of evidence. The level of recommendation ranged from $\mathrm{A}$ to $\mathrm{D}$, where $\mathrm{A}$ was the highest level of recommendation. The time frame of studies was 1991 to $2019^{(16)}$.

Six categories of non-pharmacological interventions were observed in the studies: diet supplement therapy, art therapy, therapy with physical exercises, mindfulness-based therapy, therapy with elements of nature, and psychotherapy, which were addressed as thematic axes.

Chart 2 - Characterization of studies included in this review.

\begin{tabular}{|c|c|c|c|}
\hline Authors/ country & Intervention and target audience & Outcome & $\begin{array}{l}\text { Study design/ } \\
\text { Level of evidence/ Degree } \\
\text { of recommendation }^{(16)}\end{array}$ \\
\hline $\begin{array}{l}\text { Alghamdi et al. }{ }^{(177)} \\
\text { Saudi Arabia }\end{array}$ & $\begin{array}{l}\text { Narrative exposure therapy with firefighters }(n=34) \text {. Four } \\
60-90 \text { minute sessions in } 3 \text { weeks. }\end{array}$ & $\begin{array}{l}\text { Reduction in PTSD symptom scores. } \\
\text { Results not maintained after } 3 \text { and } 6 \\
\text { months. }\end{array}$ & $\begin{array}{l}\text { Randomized controlled } \\
\text { clinical trial / 1B / A. }\end{array}$ \\
\hline $\begin{array}{l}\text { Bryant et al. }{ }^{(18) /} \\
\text { England }\end{array}$ & $\begin{array}{l}\text { Cognitive behavioral therapy with emergency responders } \\
(n=100) \text {. Weekly sessions for } 12 \text { weeks. }\end{array}$ & $\begin{array}{l}\text { Reduction in PTSD symptom scores, } \\
\text { anxiety and maladaptation. }\end{array}$ & $\begin{array}{l}\text { Randomized controlled } \\
\text { clinical trial / 1B / A. }\end{array}$ \\
\hline $\begin{array}{l}\text { Gersons et al. }{ }^{(19) /} \text { the } \\
\text { Netherlands }\end{array}$ & $\begin{array}{l}\text { Brief eclectic psychotherapy comprised of } \\
\text { psychoeducation, imaginary guidance, writing } \\
\text { assignments and memories, domain of meaning or } \\
\text { integration, and a farewell ritual for police officers } \\
(\mathrm{n}=42) \text {. Weekly } 60-90 \text { minute sessions for } 16 \text { weeks. }\end{array}$ & $\begin{array}{l}\text { Reduction in PTSD symptom scores, } \\
\text { with sustained improvement after } 3 \\
\text { months of treatment. }\end{array}$ & $\begin{array}{l}\text { Randomized non- } \\
\text { controlled clinical trial / } \\
\text { 2B / B. }\end{array}$ \\
\hline $\begin{array}{l}\text { Haugen et al. }{ }^{(20) /} \\
\text { USA }\end{array}$ & $\begin{array}{l}\text { Cognitive therapy associated with virtual reality with } \\
\text { police officers, firefighters and lay rescuers ( } n=21) \text {; eye } \\
\text { movement desensitization and reprocessing (EMDR) } \\
\text { with police officers }(n=62) \text {; therapy of behavioral } \\
\text { activation and prolonged exposure in police officers } \\
(n=1) \text {; combination of cognitive behavioral therapy and } \\
\text { eclectic psychotherapy with police officers }(n=42) \text {. }\end{array}$ & $\begin{array}{l}\text { Reduction in PTSD symptom scores } \\
\text { in most studies. Except for one study } \\
\text { that published an expert opinion about } \\
\text { EMDR. }\end{array}$ & $\begin{array}{l}\text { Systematic review with } \\
\text { no meta-analysis / } 2 \mathrm{~A} \\
\text { / B. }\end{array}$ \\
\hline $\begin{array}{l}\text { Hauger et al. }{ }^{(21) /} \\
\text { USA }\end{array}$ & $\begin{array}{l}\text { Cognitive behavioral therapy - integrative psychotherapy } \\
\text { comprising emphasis on the generation of meaning, } \\
\text { focus on the components with major impact from } \\
\text { traumatic exposure, identification and challenge of } \\
\text { implicit strategies with lay rescuers, police officers and } \\
\text { firefighters, offered weekly. }\end{array}$ & $\begin{array}{l}\text { Restored 'sense of purpose in life' and } \\
\text { 'hope for the future.' }\end{array}$ & Case report / 4 / C. \\
\hline
\end{tabular}


...continuation

\begin{tabular}{|c|c|c|c|}
\hline Authors/ country & Intervention and target audience & Outcome & $\begin{array}{l}\text { Study design/ } \\
\text { Level of evidence/ Degree } \\
\text { of recommendation }\end{array}$ \\
\hline $\begin{array}{l}\text { Haugen et al. }{ }^{.22) /} \\
\text { USA }\end{array}$ & $\begin{array}{l}\text { Integrative psychotherapy with elements of } \\
\text { psychodynamics and cognitive behavioral therapy in } \\
\text { police officers, firefighters, rescuers }(n=36) \text {. Weekly } \\
\text { sessions for 3-15 weeks }\end{array}$ & $\begin{array}{l}\text { Reduction in PTSD symptom scores in } \\
\text { most participants. About } 1 / 3 \text { of them } \\
\text { presented worsened symptoms after } 3 \\
\text { sessions. }\end{array}$ & $\begin{array}{l}\text { Exploratory cohort / 2B } \\
\text { / B. }\end{array}$ \\
\hline $\begin{array}{l}\text { Lansing et al. }{ }^{(23) /} \\
\text { USA }\end{array}$ & EMDR in police officers $(n=6) ; 33-4$ hour sessions. & $\begin{array}{l}\text { Reduction in PTSD symptom scores. } \\
\text { Changes in brain imaging tests. }\end{array}$ & $\begin{array}{l}\text { Randomized non- } \\
\text { controlled clinical trial / } \\
2 \mathrm{~B} / \mathrm{B} \text {. }\end{array}$ \\
\hline $\begin{array}{l}\text { Lewis-Schroeder et } \\
\text { al. }{ }^{(24) / \text { England }}\end{array}$ & $\begin{array}{l}\text { Cognitive processing therapy, prolonged exposure } \\
\text { therapy, and EMDR in emergency responders, pre- } \\
\text { hospital professionals, paramedics, firefighters, and law } \\
\text { enforcement officers. Weekly sessions for } 12 \text { weeks. }\end{array}$ & Reduction in PTSD symptom scores. & $\begin{array}{l}\text { Integrative review with } \\
\text { analysis of results / } 2 \text { C } \\
\text { / B. }\end{array}$ \\
\hline Nishi et al. ${ }^{(25)} /$ Japan & $\begin{array}{l}\text { Fish oil supplementation to relieve PTSD symptoms } \\
\text { in emergency physicians and nurses, lay rescuers and } \\
\text { mobile medical team who worked in the Great East } \\
\text { Japan earthquake }(n=450) \text {. } \\
\text { Seven } 320 \text { mg capsules of omega } 3 \text { were administered } \\
\text { daily for } 12 \text { weeks. }\end{array}$ & $\begin{array}{l}\text { The study did not demonstrate superiority } \\
\text { of supplementation with fish oil + } \\
\text { psychoeducation over psychoeducation } \\
\text { in reducing PTSD symptom scores. } \\
\text { Fish oil played an important role in } \\
\text { regulating psychological well-being in } \\
\text { women. }\end{array}$ & $\begin{array}{l}\text { Randomized controlled } \\
\text { clinical trial / 1B / A. }\end{array}$ \\
\hline Olden et al. ${ }^{(26)} /$ USA & $\begin{array}{l}\text { Exposure therapy via telehealth video conferencing for } \\
\text { firefighters, police, emergency and military personnel } \\
(\mathrm{n}=7) \text {. Weekly } 90 \text {-minute sessions for } 12-15 \text { weeks. }\end{array}$ & Reduction in PTSD symptom scores. & $\begin{array}{l}\text { Randomized non- } \\
\text { controlled clinical trial / } \\
\text { 2B / B. }\end{array}$ \\
\hline $\begin{array}{l}\text { Richards, } \operatorname{Rose}^{(27) /} \\
\text { England }\end{array}$ & $\begin{array}{l}\text { Cognitive behavioral therapy - in vivo exposure and } \\
\text { image exposure among police officers, one electrician } \\
\text { and one civilian }(n=4) \text {. One weekly session of } 60 \text { to } 90 \\
\text { minutes for } 7-11 \text { weeks. }\end{array}$ & Reduction in PTSD symptom scores. & Case report / 4 / C \\
\hline $\begin{array}{l}\text { Ressler, Mayberg }{ }^{(28) /} \\
\text { USA }\end{array}$ & $\begin{array}{l}\text { Art therapy - assembly of paintings and written } \\
\text { expression with military personnel }(n=240) \text {. Weekly } \\
\text { group sessions, for } 4 \text { weeks. }\end{array}$ & $\begin{array}{l}\text { Stronger feelings of hope, positive } \\
\text { emotions, socialization, self-awareness } \\
\text { of psychological impacts, reduced } \\
\text { anxiety. }\end{array}$ & $\begin{array}{l}\text { Observations of clinical } \\
\text { evolution / } 2 \mathrm{C} / \mathrm{B} \text {. }\end{array}$ \\
\hline $\begin{array}{l}\text { Berberian et al. }{ }^{(29) /} \\
\text { USA }\end{array}$ & $\begin{array}{l}\text { Occupational therapy using sports (surfing) and narrative } \\
\text { sessions with military war veterans }(n=14) \text {. Weekly } \\
\text { 4-hour sessions for } 5 \text { weeks. }\end{array}$ & $\begin{array}{l}\text { Reduction in PTSD symptom scores } \\
\text { after } 5 \text { weeks; reduction of depressive } \\
\text { symptoms. }\end{array}$ & Cohort study / 2B / B. \\
\hline $\begin{array}{l}\text { Rogers et al. }{ }^{(30) /} \\
\text { USA, Australia, } \\
\text { Israel, Croatia, } \\
\text { England }\end{array}$ & $\begin{array}{l}\text { Sports with military war veterans (total } n=4,013 \text { ). Varied } \\
\text { duration, according to the study. }\end{array}$ & \begin{tabular}{|l|} 
Reduction of stress marker \\
neurotransmitters, increased motivation, \\
reduction in PTSD symptom scores, \\
stronger positive feelings.
\end{tabular} & $\begin{array}{l}\text { Systematic review with } \\
\text { no meta-analysis / } 2 \mathrm{~A} \\
\text { / B. }\end{array}$ \\
\hline 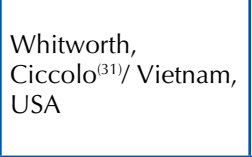 & $\begin{array}{l}\text { Mind-body interventions (stress reduction based on } \\
\text { mindfulness, in-person and telehealth mind-body therapy } \\
\text { and yoga) with military war veterans (total } n=479 \text { ). } \\
\text { Sessions varied between weekly } 90 \text {-minute sessions for } 2 \\
\text { weeks, and weekly 90-minute sessions for } 12 \text { weeks. }\end{array}$ & $\begin{array}{l}\text { Reduction in PTSD symptom scores } \\
\text { with follow-up assessment. }\end{array}$ & $\begin{array}{l}\text { Systematic review with } \\
\text { no meta-analysis / } 2 \mathrm{~A} \\
\text { / B. }\end{array}$ \\
\hline $\begin{array}{l}\text { Cushing, Braun }{ }^{(32) /} \\
\text { USA }\end{array}$ & $\begin{array}{l}\text { Transcendental meditation with military personnel } \\
(\mathrm{n}=74) \text {. Group and individual sessions of } 1.5 \text { to } 2 \text { hours, } \\
5 \text { days a week, for } 3 \text { months (at least). }\end{array}$ & $\begin{array}{l}\text { Reduction in the use of psychotropic } \\
\text { drugs, reduction in PTSD symptom } \\
\text { scores. }\end{array}$ & Cohort study / 2B / B. \\
\hline Barnes et al. ${ }^{(33) /}$ USA & $\begin{array}{l}\text { Mindfulness-based stress reduction with military war } \\
\text { veterans }(\mathrm{n}=8) \text {. Weekly group sessions for } 8 \text { weeks. }\end{array}$ & Reduction in PTSD symptom scores. & $\begin{array}{l}\text { Observations of clinical } \\
\text { evolution / 2C / B. }\end{array}$ \\
\hline $\begin{array}{l}\text { Bhatnagar et al. }{ }^{(34) /} \\
\text { USA }\end{array}$ & $\begin{array}{l}\text { Transcendental meditation versus prolonged exposure } \\
\text { therapy with military war veterans }(n=203) \text {. Weekly } \\
\text { group and individual sessions for } 12 \text { weeks. }\end{array}$ & $\begin{array}{l}\text { Reduction in similar PTSD symptom } \\
\text { scores in both interventions, } \\
\text { making transcendental meditation a } \\
\text { therapeutic alternative. }\end{array}$ & $\begin{array}{l}\text { Randomized controlled } \\
\text { clinical trial / 1B / A. }\end{array}$ \\
\hline Nidich et al. ${ }^{(35) /}$ USA & $\begin{array}{l}\text { Horticultural therapy with military war veterans }(n=49) \text {. } \\
\text { Supervised sessions of up to } 5 \text { hours a day, for } 3 \text { weeks. }\end{array}$ & $\begin{array}{l}\text { Very small reduction in stress levels } \\
\text { and PTSD symptom scores. }\end{array}$ & $\begin{array}{l}\text { Randomized clinical trial } \\
\text { / } 2 \mathrm{~B} / \mathrm{B} \text {. }\end{array}$ \\
\hline $\begin{array}{l}\text { Detweiler et al. }{ }^{(36) /} \\
\text { Australia }\end{array}$ & $\begin{array}{l}\text { Animal-assisted therapy using service dogs with military } \\
\text { personnel }(n=7) \text {. }\end{array}$ & $\begin{array}{l}\text { Increased sense of security, reduced } \\
\text { isolation, reduced anxiety, improved } \\
\text { sleep, better control of anger, reduced } \\
\text { use of medications. }\end{array}$ & Case report / 4 / C \\
\hline $\begin{array}{l}\text { McLaughlin, } \\
\text { Hamilton }^{(37) /} \text { USA }\end{array}$ & $\begin{array}{l}\text { Animal-assisted therapy, through interaction with } \\
\text { pinnipeds (seals) and military veteran personnel }(n=4) \text {. } \\
\text { Three sessions of } 1 \text { hour each, with interactions showing } \\
\text { how to take care of and treat the animals. }\end{array}$ & Reduction in PTSD symptom scores. & Case report / 4 / C. \\
\hline $\begin{array}{l}\text { Wortman et al. }{ }^{(38) /} \\
\text { USA }\end{array}$ & $\begin{array}{l}\text { Yoga practice with military veteran personnel }(n=25) \text {; } \\
22 \text { hours of group yoga practice for } 5 \text { days, followed by } \\
\text { weekly 2-hour group sessions for } 5 \text { months. }\end{array}$ & $\begin{array}{l}\text { Reduction in PTSD symptom scores, } \\
\text { with 6-month follow-up. }\end{array}$ & $\begin{array}{l}\text { Randomized controlled } \\
\text { clinical trial / 1B / A. }\end{array}$ \\
\hline Carter et al. ${ }^{(39)} /$ USA & $\begin{array}{l}\text { Mindfulness-based stretching and deep breathing } \\
\text { exercise (MBX) with nurses }(n=29) ; 16 \text { weekly 60-minute } \\
\text { sessions. }\end{array}$ & $\begin{array}{l}\text { Reduction in serum cortisol levels } \\
\text { associated with reduction in PTSD } \\
\text { symptom scores. }\end{array}$ & $\begin{array}{l}\text { Randomized controlled } \\
\text { clinical trial / 1B / A. }\end{array}$ \\
\hline
\end{tabular}


Supplementation with omega 3 capsules was observed in only one study. The fatty acids in omega 3 are precursors of cerebral hippocampal neurogenesis, an area related to the time during which memories linked with fear, present in PTSD, are extended ${ }^{(25)}$. This supplementation was performed with oral administration of capsules for 12 weeks. The study did not demonstrate any effects on the symptomatic treatment of PTSD, but it promoted well-being in female participants.

Other therapies found in the studies could be categorized as art therapy, which uses elements of psychology and arts, in this case, painting ${ }^{(28)}$; therapy with physical activities (sports, stretching, yoga) combined or not with mental, relaxation and/or concentration exercises ${ }^{(29-31,38-39)}$; mindfulness-based therapy with sessions of meditation (including transcendental meditation), emotional and body awareness and percep$\operatorname{tion}^{(31-34,39)}$, and therapy with elements of nature (horticultural and animal-assisted therapy) $)^{(35-37)}$; all of them showing positive results in PTSD symptoms.

Psychotherapy was another category identified in eleven studies for the treatment of PTSD in emergency responders. It influences 'mental schemas' - structures that shape one's worldview and self-view - addressing psychological aspects in order to resymbolize memories or emotions linked with traumatic memories or adapt a traumatic event to the reality of an individual( ${ }^{(21)}$.

In general, the psychotherapies found in the sample of this study can be included in three major groups: cognitivebehavioral therapy (cognitive therapy, cognitive processing therapy, brief eclectic psychotherapy) ${ }^{(18-22,24,27)}$, exposure therapy (narrative exposure therapy, prolonged exposure therapy) which is a subtype of cognitive-behavioral therapy with technical particularities ${ }^{(17,24,26,34)}$, and eye movement desensitization and reprocessing (EMDR) ${ }^{(23)}$.

The sample of this study showed different psychotherapeutic approaches. They all had in common sessions with a psychiatrist, psychologist and/or multidisciplinary team, including psychoeducation elements regarding the disease, memory of traumatic events, and event assimilation techniques.

The techniques of assimilation/resymbolization varied from guided remembrance - when the patient is instructed to remember the traumatic event, focusing on resulting sensations, and externalize them through an account to induce assimilation; resymbolization - when the event is discussed with the therapist to have an exhaustive explanation of all unpleasant feelings and sensations related, with subsequent interpretation by the patient, recognizing their behavior patterns ${ }^{(17-24,26-27)}$.

Reliving/exposure was also observed, in which the patient describes the event in present tense while the session is recorded. The audio recording is heard several times and with each new session, another audio recording is made to promote exposure to the event and generate new perspectives. EMDR was also reported, in which the therapist asks the patient to remember the traumatic event, while offering external eye movement stimulation that unconsciously reduces tension/stress related to the event ${ }^{(17-24,26-27)}$.
It is worth noting the association of psychotherapy with video conferencing, which presented an alternative to inperson sessions, increasing the convenience to emergency professionals with $\mathrm{PTSD}^{(26,31)}$.

\section{DISCUSSION}

The purpose of this review is to identify non-pharmacological therapeutic alternatives for PTSD in emergency responders. According to this review, the literature addresses six therapeutic aspects.

Diet supplement, specifically with omega 3 capsules, has not previous studies developed with human beings ${ }^{(25)}$. This study with diet supplement is linked with two other studies conducted in a laboratory with mice which indicated that the level of hippocampal neurogenesis is associated with the time during which traumatic memories present in PTSD are extended. Although not strongly recommended, since this specific study shows no statistically significant effects on PTSD, this alternative is a vast field for further investigation in the treatment of mental disorders, considering that it promoted the well-being of female participants ${ }^{(40-41)}$.

Art therapy combines elements of psychology and arts. Since 1970, art therapy has proven to be an effective alternative in the treatment of traumatic disorders, especially for individuals who are unable to express themselves orally with efficiency. Then, it is used to allow emotional expressions and details of the traumatic event through artistic and visual resources, allowing the patient to externalize conscious and unconscious components ${ }^{(28,42)}$.

It is a therapy that emphasizes the use of art in the narrative reconstruction of the traumatic event with moments of oral and/or written expression of the significance and representation of the artistic work, consequently allowing the management of stress, physical and mental symptoms related to PTSD $^{(42-43)}$.

A study conducted with therapists from the American Art Therapy Association (AATA) evaluated the therapeutic mechanisms of art therapy and found effective mechanisms particularly for the treatment of reliving and hyperexcitability symptoms, and less effective for the avoidance symptoms, through seven mechanisms: reconsolidation of memories (promoting defragmentation of memories related to the traumatic event), progressive exposure (for the production of works of art, stimulating mechanisms contrary to the avoidance symptoms), externalization (moments with narration of events), reduction of triggers (through relaxation and concentration promoted by manual work), reactivation of positive emotions (by the feeling of pleasure and satisfaction promoted by the artistic moment, as reported by the individuals), improvement of emotional self-efficacy (enhancing self-confidence while expressing emotions), and enhanced self-esteem ${ }^{(42)}$.

Therapy with physical activities promotes physical stimulation which, in turn, will improve psychological aspects. Studies indicate that sports and physical activities can improve the quality of life and well-being, enhance determination, improve the response to stress by decreasing serum cortisol levels. These studies also suggest that these are good 
therapeutic options for professionals who work in situations which stimulate peak adrenaline levels, as emergency responders ${ }^{(29-30,44)}$.

Although few studies provide evidence on the effectiveness of this therapy for the treatment of PTSD, the studies included in this review presented degree of recommendation $\mathrm{B}$, in agreement with two prior reviews that highlighted the beneficial effects on symptoms of depression, stress, improvements in anxiety control and mechanisms to cope with negative feelings - manifestations present in $\mathrm{PTSD}^{(45-46)}$.

In addition to sports, yoga, also included in the category of physical exercises, is an integrative practice that connects body and mind to treat traumas by adopting physical exercises, positions, breathing techniques, introspection and meditation that help develop neural connections, which enable the identification of introspective awareness and reduce negative mental states ${ }^{(38,47)}$.

Other practices that are similar to yoga are found in the mindfulness therapy. Based on the individual's awareness, attention and memory, mindfulness derives from some Buddhist concepts. This method allows full awareness and perception of the body and mind and helps reduce and eliminate negative emotions present in PTSD, considering that emotions depend on the mind itself, and not on external circumstances $^{(48)}$. This therapy includes activities in a state of increased awareness, free of judgments, as seen in meditation (self-guided activity, with eyes closed, in a conscious state), transcendental meditation (meditation while listening to mantras), and mindfulness-based stretching exercises and deep breathing (mindfulness-based stretching and deep breathing exercise - MBX12 - a set of 12 fluid and connected movements). These therapies act on thinking processes, with the patient in a vigilant hypometabolic state characterized by increased neural coherence and physiological rest, reducing cortisol, C-reactive protein, tumor necrosis factor alpha, triglycerides, heart rate, and blood pressure ${ }^{(32-34,48)}$.

Therapy with elements of nature finds support in several disciplines, one of them in Wilson's hypothesis of biophilia, in which as a consequence of evolution, the contact with nature would improve psychological well-being. This type of therapy reduces the activity of the prefrontal cortex while the activity of the parasympathetic nervous system increases, with a consequent reduction in blood pressure and heart rate, thus causing a feeling of relaxation and reducing stress ${ }^{(49-50)}$.

In this category, horticultural therapy refers to an activity in which an individual has contact with a vegetable garden, receiving guidance from a trained therapist on how to plant, maintain and harvest it, aiming to reach goals in the treatment of PTSD or other psychological conditions. Its benefits include stress reduction, improvements in the feeling of fun, attention, cognition, well-being, and quality of life ${ }^{(35,51)}$.

The study with pinnipeds (seals) found in the literature was based on human-animal interaction in a pilot study that aimed to promote education on ocean ecology, distribution and habitat of seals, anatomy and physiology, breeding, preparation of meals, and direct interactions. The study with service dogs differed from previous studies with therapy dogs, since they were trained to act in emergencies and assisted PTSD patients in resuming daily activities ${ }^{(36-37)}$.

Both studies are characterized as animal-assisted therapies, which are therapeutic practices conducted by health or education professionals or trained psychologists who understand the animal needs and health. The scientific community proposes that human interactions with animals can regulate the hypothalamic-pituitary-adrenal axis and the autonomic nervous system and promote positive physiological effects, including good levels of cortisol, heart rate and blood pressure. Closer contact with the animal can also increase the levels of oxytocin and dopamine ${ }^{(52)}$.

Psychotherapy is widely studied in populations suffering from traumatic events and has been adapted to the treatment of PTSD, with studies analyzing samples of military personnel and war veterans presenting symptoms that are compatible with this psychopathology $\mathrm{y}^{(12)}$.

Cognitive-behavioral therapy has a didactic character as it teaches how to identify automatic negative thought patterns, including the psychological and physiological responses resulting from them, and provides strategies to deal with them positively. Exposure therapy is based on the theory that repeated exposure to traumatic memories within a controlled environment generates habituation to situations involving fear and modification in the avoidance systems present in PTSD. It rescues resilient attitudes in memory, imaginary or real exposure to situations related to the traumatic event and cognitive restructuring. And EMDR is a technique that offers visual, auditory and/or tactile stimulation simultaneously with verbalization of traumatic events and resymbolization of these memories ${ }^{(53-55)}$.

It is worth noting that the psychotherapeutic approach also addresses 'repetition compulsion,' in which the subject who suffered a trauma acts under an instinctive impulse to relive the experiences, whether through memory, dissociations or other manifestations which are derived, according to the studies, from a defense of 'mental schemas' that are not well adapted to the new post-event situations ${ }^{(10,21)}$.

Some other authors refer to these 'mental schemas' as ego, referring to Freud's concept of mediator of the personality. They argue that ego in a person with PTSD would block one's understanding and awareness of these stressful events and, therefore, it involves the symptoms of reliving not only memories and dreams, but also sensations and behaviors similar to those experienced in the traumatic event ${ }^{(56)}$.

Studies report that a 'strict' ego, that is, overestimated selfperceptions or inflexible perception of changes in opinions or scenarios, poses a higher risk of developing PTSD ${ }^{(57)}$. This phenomenon is often reported in studies with professionals who work in risky situations and put themselves in emergencies to save others, denying themselves and considering failure as an unacceptable outcome ${ }^{(56)}$.

Psychotherapy proposes to stabilize the subject by finding the cause of the trauma, decoding symptomatic responses, promoting a restructuring in thinking patterns and rehabilitating the individual to new and/or similar situations, as addressed in all studies in this review ${ }^{(58-59)}$. Also, the following factors must be taken into account: the therapist's 
skills, and patient needs and preferences for one or another psychotherapeutic approach ${ }^{(11)}$.

The results of this review support the recommendations of national and international psychology and psychiatry associations, as well as protocols, guidelines and manuals that indicate psychotherapy as the most strongly recommended therapy. However, the results showed other therapeutic alternatives not addressed in most recommendations, as they are less explored when compared to psychotherapy ${ }^{(4,6-9)}$.

In addition to supporting existing recommendations, this review also support the therapies described in the technical guide for PTSD treatment issued by the Ministry of Justice and Public Security of Brazil, such as meditation, yoga, acupuncture, and reiki (not identified in studies in this review $)^{(5)}$. This review study also showed an innovative aspect regarding the use of telehealth video conferencing in psychotherapy, demonstrating similar efficiency to that of the in-person meetings ${ }^{(26)}$. This technology offers a solution to the physical and emotional barriers faced by patients when seeking face-to-face care in health services. It also confirms the worldwide technological trend of some telehealth services that are equivalent to those provided face to face, although further studies are needed to confirm their use in the treatment of PTSD ${ }^{(60)}$.

Regarding limitations, despite our efforts to develop a comprehensive search strategy, the sample in this review may not have included a relevant study to these results. Also, even if the studies mostly presented degree of evidence 2 and level of recommendation $\mathrm{B}$, the evidence was extracted from reviews or studies with reduced samples (or not representative of all the categories that comprise emergency professionals), making it difficult to generalize results.

This gap in the literature was also identified by previous studies, which pointed to a low number of studies about the treatment of PTSD among emergency responders, considering that their work conditions involve continuous and prolonged exposures to potentially traumatic situations ${ }^{(61)}$. However, despite this gap, the studies have presented approaches already used on a large scale in similar studies with patients receiving PTSD treatment.

Another gap observed in this review refers to studies evaluating therapies such as acupuncture, music therapy and other types of emerging therapies for the treatment of PTSD among emergency responders, since treatment with this population may differ from that for civilians, due to their work nature, according to a review ${ }^{(62)}$. Therefore, further studies must be conducted to generate evidence and expand the range of therapies for the treatment of PTSD in emergency responders.

\section{CONCLUSION}

As implications for the practice, this review helped identify the therapy with diet supplement as a field for further investigation in the treatment of mental disorders.

Psychotherapy was identified as the most common nonpharmacological therapy, recommended and described in the literature for the treatment of PTSD in emergency responders; it involves several approaches, offering alternatives that support the recommendations in national and international manuals available for clinical practice. It also described art therapy, physical exercise therapy, mindfulness-based therapy, and therapy with elements of nature as therapeutic alternatives for the treatment of PTSD.

It also showed the use of telehealth as an alternative in the psychotherapeutic approach and highlighted that further studies must be conducted addressing the treatment of PTSD with larger and more comprehensive samples of emergency responders, and assessing other alternative therapies.

\section{RESUMO}

Objetivo: Identificar as terapias não farmacológicas utilizadas no tratamento do transtorno de estresse pós-traumático em profissionais emergencistas. Método: Revisão de escopo conforme orientações do Instituto Joanna Briggs e do protocolo PRISMA-ScR. A busca foi realizada em nove bases de dados, portais de teses e dissertações e por meio de buscador eletrônico. Resultados: Foram selecionados e caracterizados 23 estudos, que foram categorizados em seis eixos temáticos, sendo eles: terapia com suplementação alimentar com ômega 3, arteterapia, terapia com exercícios físicos, terapia envolvendo a técnica mindfulness, terapia com elementos da natureza e psicoterapia, que foram apontados como tratamentos não farmacológicos para esta psicopatologia em profissionais emergencistas e, ainda, o recurso da psicoterapia via telessaúde como uma alternativa no tratamento. Conclusão: É necessário maior número de evidências que suportem a terapia dietética, enquanto as demais alternativas terapêuticas encontradas apresentaram resultados positivos, encontrando suporte nas recomendações nacionais e internacionais de tratamento e prática clínica.

\section{DESCRITORES}

Transtornos de Estresse Pós-Traumáticos; Socorristas; Terapias Complementares; Enfermagem em Emergência; Revisão.

\section{RESUMEN}

Objetivo: Identificar las terapias no farmacológicas utilizadas para tratamiento del trastorno de estrés postraumático en profesionales emergencistas. Método: Revisión de alcance conforme indicaciones del Instituto Joanna Briggs y del protocolo PRISMA-ScR. Búsqueda realizada en nueve bases de datos, portales de tesis y disertaciones, y mediante buscador electrónico. Resultados: Fueron seleccionados y caracterizados 23 estudios, categorizados en seis ejes temáticos, a saber: terapia con suplemento alimentario de omega 3; arteterapia, terapia con ejercicios físicos, terapia con técnica de mindfulness, terapia con elementos de la naturaleza y psicoterapia, todos ellos destacados como tratamientos no farmacológicos para esta patología en profesionales emergencistas, así como el recurso de la psicoterapia vía telesalud como alternativa de tratamiento. Conclusión: Se necesita mayor cantidad de evidencias respaldando la terapia alimentaria, mientras que las demás alternativas terapéuticas encontradas demostraron resultados positivos, hallando respaldo en recomendaciones nacionales e internacionales de tratamiento y práctica clínica.

\section{DESCRIPTORES}

Trastornos por Etrés Postraumático; Socorristas; Terapias Complementarias; Enfermería de Urgencia; Revisión. 


\section{REFERENCES}

1. American Psychiatric Association. Diagnostic and statistical manual of mental disorders. $5^{\text {th }}$ ed. Washington: APA; 2013.

2. Pai A, Suris AM, North CS. Posttraumatic stress disorder in the DSM-5: controversy, change, and conceptual considerations. Behav Sci. 2017;7(1):7. doi: http://dx.doi.org/10.3390/bs7010007

3. Tuckey MR, Scott JE. Group critical incident stress debriefing with emergency services personnel: a randomized controlled trial. Anxiety Stress Coping. 2014;27(1):38-54. doi: http://dx.doi.org/10.1080/10615806.2013.809421

4. American Psychiatric Association. Practice guideline for the treatment of patients with acute stress disorder and posttraumatic stress disorder. Am J Psychiatry. 2004;161;(11 Suppl):3-31.

5. Brasil. Ministério da Justiça e Segurança Pública, Secretaria Nacional de Segurança Pública. Caderno técnico de tratamento do transtorno de estresse pós-traumático-TEPT [Internet]. Brasília; 2019 [citado 2020 jul. 30]. Disponível em: https://legado.justica.gov.br/news/ collective-nitf-content-1570038268.58/caderno-tecnico-de-tratamento-do-transtorno-de-estresse-pos-traumatico-tept.pdf

6. Santa Catarina. Rede de Atenção Psicossocial - RAPS. Transtorno de estresse pós-traumático: protocolo clínico [Internet]. Florianópolis; 2015 [citado 2020 jul. 30]. Disponível em: https://www.saude.sc.gov.br/index.php/documentos/atencao-basica/saude-mental/protocolosda-raps/9206-estresse-pos-traumatico/file

7. Forbes D, Creamer M, Phelps A, Bryant R, McFarlane A, Devilly GJ, et al. Australian guidelines for the treatment of adults with acute stress disorder and post-traumatic stress disorder. Aust N Z J Psychiatry. 2007;41(8):637-48. doi: http://dx.doi.org/10.1080/00048670701449161

8. USA. Department of Veterans Affairs; Department of Defense. Management of Post-Traumatic Stress Working Group. VA/DOD clinical practice guideline for management of post-traumatic stress [Internet]. Washington; 2017 [cited 2020 July 30]. Available from: https://www. healthquality.va.gov/guidelines/MH/ptsd/VADoDPTSDCPGFinal012418.pdf

9. Katzman MA, Bleau P, Blier P, Chokka P, Kjernisted K, Ameringen MV, et al. Canadian clinical practice guidelines for the management of anxiety, posttraumatic stress and obsessive-compulsive disorders. BMC Psychiatry. 2014;14 Suppl 1:S1. doi: http://dx.doi.org/10.1186/1471244X-14-S1-S1

10. Price JP. Cognitive schemas, defence mechanisms and post-traumatic stress symptomatology. Psychol Psychother Theory Res Pract. 2007;80(3):343-53. doi: https://doi.org/10.1348/147608306X144178

11. Lancaster CL, Teeters JB, Gros DF, Back SE. Posttraumatic stress disorder: overview of evidence-based assessment and treatment. J Clin Med. 2016;5(11):105. doi: https://doi.org/10.3390/jcm5110105

12. American Psychological Association. Clinical practice guideline for the treatment of posttraumatic stress disorder (PTSD) in adults. Washington: APA; 2017.

13. Joana Briggs Institute. Reviwers' manual 2020: metodology for JBI scoping reviews [Internet]. Adelaide: JBI; 2020 [cited 2020 July 28 ]. Available from: https://wiki.jbi.global/display/MANUAL/Chapter+11\%3A+Scoping+reviews

14. Peters MDJ. Joanna Briggs institute reviewer's manual. Adelaide: JBI; 2017.

15. Tricco AC, Lillie E, Zarin W, O'Brien KK, Colquhoun H, Levac D. PRISMA extension for scoping reviews (PRISMA-ScR): checklist and explanation. Ann Intern Med. 2018;169:467-73. doi: https://doi.org/10.7326/M18-0850

16. Centre for Evidence-Based Medicine. Levels of evidence [Internet]. Washington: CDC; 2009 [cited 2020 July 29]. Available from: https:// www.cebm.net/2009/06/oxford-centre-evidence-based-medicine-levels-evidence-march-2009/

17. Alghamdi M, Hunt N, Thomas S. The effectiveness of narrative exposure therapy with traumatised firefighters in Saudi Arabia: a randomized controlled study. Behav Res Ther. 2015; 66:64-71. doi: https://doi.org/10.1016/j.brat.2015.01.008

18. Bryant RA, Kenny L, Rawson N, Cahill C. Efficacy of exposure-based cognitive behaviour therapy for post-traumatic stress disorder in emergency service personnel: a randomised clinical trial. Psychol Med. 2019;49(9):1565-73. doi: https://doi.org/10.1017/ S0033291718002234

19. Gersons BPR, Carlier IVE, Lamberts RD, Kolk BAVD. Randomized clinical trial of brief eclectic psychotherapy for police officers with posttraumatic stress disorder. J Trauma Stress. 2000;13(2):333-47. doi: https://doi.org/10.1023/A:1007793803627

20. Haugen PT, Evces T, Weiss DS. Treating posttraumatic stress disorder in first responders: a systematic review. Clin Psychol Rev. 2012;32(5):370-80. doi: https://doi.org/10.1016/j.cpr.2012.04.001

21. Hauger PT, Splaun AK, Evces MR, Weiss DS. Integrative approach for the treatment of posttraumatic stress disorder in 9/11 first responders: three core techniques. Psychotherapy (Chic). 2013;50(3):336-40. doi: https://doi.org/10.1037/a0032526

22. Haugen P, Goldman R, Owen J. Sudden gains and deteriorations in the treatment of posttraumatic stress disorder in World Trade Center responders. J Nerv Ment Dis. 2015; 203(3):205-9. doi: https://doi.org/10.1097/NMD.0000000000000263

23. Lansing K, Amen DG, Hanks C, Rudy L. High-resolution brain SPECT imaging and eye movement desensitization and reprocessing in police officers with PTSD. J Neuropsychiatry Clin Neurosci. 2005;10(1):526-32. doi: https://doi.org/10.1176/jnp.17.4.526

24. Lewis-Schroeder NF, Kieran KNP, Murphy BLMD, Wolff JDBS, Robinson MA, Kaufman MLMD. Conceptualization, assessment, and treatment of traumatic stress in first responders: a review of critical issues. Harv Rev Psychiatry. 2018;26(4):216-27. doi: https://doi. org/10.1097/HRP.0000000000000176

25. Nishi D, Koido Y, Nakaya N, Noguchi H, Hamazaki K, Hamazaki T, et al. Fish oil for attenuating posttraumatic stress symptoms among rescue workers after the great east Japan earthquake: a randomized controlled trial. Psychother Psychosom. 2012;81:315-7. doi: https:// doi.org/10.1159/000336811

26. Olden M, Wyka K, Cukor J, Peskin M, Altemus M, Lee F. Pilot study of a telehealth-delivered medication-augmented exposure therapy protocol for PTSD. J Nerv Ment Dis. 2017; 205(2):154-160. doi: https://doi.org/10.1097/NMD.0000000000000563

27. Richards, DA, Rose, JS. Exposure therapy for post-traumatic stress disorder: four case studies. Br J Psychiatry. 1991;158(6):836-40. doi: https://doi.org/10.1192/bjp.158.6.836 
28. Ressler KJ, Mayberg HS. Targeting abnormal neural circuits in mood and anxiety disorders: from the laboratory to the clinic. Nat Neurosci. 2007; 10:1116-24. doi: https://doi.org/10.1038/nn1944

29. Berberian M, Walker MS, Kaimal G. 'Master my demons': art therapy montage paintings by active-duty military service members with traumatic brain injury and post-traumatic stress. Med Humanit. 2019;45(4):353-60. doi: http://dx.doi.org/10.1136/medhum-2018-011493

30. Rogers CM, Mallinson T, Peppers D. High-intensity sports for posttraumatic stress disorder and depression: feasibility study of ocean therapy with veterans of operation enduring freedom and operation Iraqi freedom. Am J Occup Ther. 2014;68(4):395-404. doi: http:// dx.doi.org/10.5014/ajot.2014.011221

31. Whitworth JW, Ciccolo JT. Exercise and post-traumatic stress disorder in military veterans: a systematic review. Mil Med. 2016; 181:953960. doi: http://dx.doi.org/10.7205/MILMED-D-15-00488

32. Cushing RE, Braun KL. Mind-body therapy for military veterans with post-traumatic stress disorder: a systematic review. J Altern Complement Med. 2018;24(2):106-14. doi: http://dx.doi.org/10.1089/acm.2017.0176

33. Barnes VA, Monto A, Williams JJ, Rigg JL. Impact of transcendental meditation on psychotropic medication use among active duty military service members with anxiety and PTSD. Mil Med. 2016;181:56-63. doi: http://dx.doi.org/10.7205/MILMED-D-14-00333

34. Bhatnagar R, Phelps L, Rietz K, Juergens T, Russell D, Miller N, et al. The effects of mindfulness training on post-traumatic stress disorder symptoms and heart rate variability in combat veterans. J Altern Complement Med. 2013;19(11):860-1. doi: http://dx.doi.org/10.1089/ acm.2012.0602

35. Nidich PS, Mills PJ, Rainforth M, Heppner P, Schneider PRH, Rosenthal PNER, et al. Non-trauma-focused meditation versus exposure therapy in veterans with post-traumatic stress disorder: a randomised controlled trial. Lancet Psychiat. 2018;5(12):975-86. doi: http:// dx.doi.org/10.1016/S2215-0366(18)30384-5

36. Detweiler MB, Self JA, Lane S, Spencer L, Lutgens B, Kim DY, et al. Horticultural therapy: a pilot study on modulating cortisol levels and indices of substance craving, posttraumatic stress disorder, depression, and quality of life in veterans. Altern Ther Health Med. 2015;21(4):36-41. Available from: https://pubmed.ncbi.nlm.nih.gov/26030115/

37. McLaughlin K, Hamilton AL. Exploring the influence of service dogs on participation in daily occupations by veterans with PTSD: A pilot study. Aust Occup Ther J. 2019;66:648-55. doi: http://dx.doi.org/10.1111/1440-1630.12606

38. Wortman RA, Vallone T, Karnes M, Walawander C, Daly D, Fox-Garrity B. Pinnipeds and PTSD: an analysis of a human-animal interaction case study program for a veteran. Occup Ther Int. 2018;2018:2686728. doi: http://dx.doi.org/10.1155/2018/2686728

39. Carter JJ, Gerbarg PL, Brown R, Ware RS, D'Ambrosio C, Anand L, et al. Multi-component yoga breath program for Vietnam veteran post traumatic stress disorder: randomized controlled trial. Trauma Stress Disor Treat. 2013;2:1-10. doi: http://dx.doi.org/10.4172/23248947.1000108

40. Kim SH, Schneider SM, Bevans M, Kravitz L, Mermier C, Qualls C, et al. PTSD symptom reduction with mindfulness-based stretching and deep breathing exercise: randomized controlled clinical trial of efficacy. J Clin Endocrinol Metab. 2013; 98(7):2984-92. doi: http:// dx.doi.org/10.1210/jc.2012-3742

41. Kitamura T, Saitoh Y, Takashima N, Sekiguch M, Sugiyama H, Inokuchi K. Adult neurogenesis modulates the hippocampus-dependent period of associative fear memory. Cell. 2009;139(4):814-27. doi: https://doi.org/10.1016/j.cell.2009.10.020

42. Collie K, Backos A, Malchiodi C, Spiegel D. Art therapy for combat-related PTSD: recommendations for research and practice. Art Ther (Alex). 2006;23(4):157-64. doi: https://doi.org/10.1080/07421656.2006.10129335

43. Kaimal G, Jones JP, Dieterich-Hartwell R, Acharya B, Wang X. Evaluation of long- and short-term art therapy interventions in an integrative care setting for military service members with post-traumatic stress and traumatic brain injury. Art Psychother. 2019; 62:28-36. doi: https:// doi.org/10.1016/j.aip.2018.10.003

44. Ley C, Barrio MR, Koch A. "In the sport I am here": therapeutic processes and health effects of sport and exercise on PTSD. Qual Health Res. 2017;28(3):491-507. doi: http://dx.doi.org/10.1177/1049732317744533

45. Ensari I, Greenlee TA, Motl RW, Petruzzello SJ. Meta-analysis of acute exercise effects on state anxiety: an update of randomized controlled trials over the past 25 years. Depress Anxiety. 2015; 32(8):624-634. doi: http://dx.doi.org/10.1002/da.22370

46. Stults-Kolehmainen MA, Sinha R. The effects of stress on physical activity and exercise. Sports Med. 2014;44(1):81-121. doi: http://dx.doi. org/10.1007/s40279-013-0090-5

47. Justice L, Brems C. Bridging body and mind: case series of a 10-week trauma-informed yoga protocol for veterans. Int J Yoga Therap. 2019;29(1):65-79. doi: http://dx.doi.org/10.17761/D-17-2019-00029

48. Sanada K, Montero-Marin J, Barceló-Soler A, Ikuse D, Ota M, Hirata A, et al. Effects of mindfulness-based interventions on biomarkers and low-grade inflammation in patients with psychiatric disorders: a meta-analytic review. Int J Mol Sci. 2020;21(7):2484. doi: https:// doi.org/10.3390/ijms21072484

49. Gullone E. The biophilia hypothesis and life in the 21st century: increasing mental health or increasing pathology?. J Happiness Stud. 2000;1:293-322. doi: https://doi.org/10.1023/A:1010043827986

50. Park SA, Song C, Oh YA, Miyazaki Y, Son KC. Comparison of physiological and psychological relaxation using measurements of heart rate variability, prefrontal cortex activity, and subjective indexes after completing tasks with and without foliage plants. Int J Environ Res Public Health. 2017;14(9):1-12. doi: https://doi.org/10.3390/ijerph14091087

51. Siu AMH, Kam M, Mok I. Horticultural therapy program for people with mental illness: a mixed-method evaluation. Int J Environ Res Public Health. 2020;17(3):711. doi: https://doi.org/10.3390/ijerph17030711

52. Santaniello A, Dicé F, Carratú RC, Amato A, Fioretti A, Menna LF. Methodological and terminological issues in animal-assisted interventions: an umbrella review of systematic reviews. Animals. 2020;10(5):1-20. doi: https://doi.org/10.3390/ani10050759

53. Beck JS. Cognitive behavior therapy: basics and beyond. $2^{\text {nd }}$ ed. New York: The Guilford; 2011. 
54. Shapiro F. Eye movement desensitization and reprocessing: basic principles, protocols and procedures. $2^{\text {nd }}$ ed. New York: The Guilford; 2001.

55. Everly Jr GS, Lating JM. A clinical guide to the treatment of the human stress response. $3^{\text {rd }}$ ed. New York: Springer; 2012.

56. Reger MG, Bourassa KJ, Smolenski D, Buck B, Noor AM. Lifetime trauma exposure among those with combat-related PTSD: psychiatric risk among U.S. military personnel. Psychiatry Res. 2019;278:309-14. doi: https://doi.org/10.1016/j.psychres.2019.06.033

57. Jeannette JM, Scoboria A. Firefighter preferences regarding post-incident intervention. Work Stress. 2008;22(4):314-26. doi: https://doi. org/10.1080/02678370802564231

58. Freeman DB. Posttraumatic stress disorder and the injured worker. Part II. Case management. 2000;11(4):45-8. doi: https://doi.org/10.1067/ mcm.2000.109130

59. Steenkamp MM, Litz BT, Hoge CW. Psychotherapy for military-related PTSD: a review of randomized clinical trials. JAMA. 2015;314(5):489500. doi: https://doi.org/10.1001/jama.2015.8370

60. Shigekawa E, Fix M, Corbett G, Roby DH, Coffman J. The current state of telehealth evidence: a rapid review. Health Aff (Millwood). 2018;37(12):1975-82. doi: https://doi.org/10.1377/hlthaff.2018.05132

61. Lowell A, Suarez-Jimenez B, Helpman L, Zhu X. 9/11-related PTSD among highly exposed populations: a systematic review 15 years after the attack. Psychol Med. 2018;48 (4):537-53. doi: https://doi.org/10.1017/S0033291717002033

62. Metcalf O, Varker T, Forbes D, Phelps A, Dell L, DiBattista A. Efficacy of fifteen emerging interventions for the treatment of posttraumatic stress disorder: a systematic review. J Trauma Stress. 2016;29:88-92. doi: https://doi.org/10.1002/jts.22070 